\title{
Impact of FDI as Macroeconomic Variable on the Exchange Rates with Special Reference to the Selected Asian Countries' Currencies
}

\author{
A.Paul Williams
}

\begin{abstract}
Globalization has brought immense benefit for the welfare of the human race. For a globalized world, the economic integration of nations around the world is a prerequisite. This integration of economies has brought in the concept of international trade wherein the countries trade with each other. For a trade to be carried out the buyer has to pay the seller in currency that is accepted by the seller. As of now one of the widely accepted currencies is USD and the exchange rates of most of the currencies are determined in terms of USD. The exchange rate of a country is affected by many macroeconomic variables and one among them is the FDI. This paper has tried to analyse whether FDI as a macroeconomic variable affects the exchange rate of selected Asian countries' currencies. With the integration of economies around the world, it is important to know the factor responsible for the variation in the exchange rates. With this knowledge, the Governments and the Central Banks can plan their policies accordingly that are attractive to the investors. The study has considered countries such as China, India, Phillipines, Qatar and Singapore. The study has used regression to find out the influence of FDI inflows on the exchange rates of respective currencies and correlation has been used to find the extent of relationship between the variables considered. The results show that the FDI inflows affect the exchange rates of all the countries considered except Phillipines. Also correlation shows that FDI inflows and Exchange rates of Qatar are not related since Qatar follow fixed exchange rate regime.
\end{abstract}

\section{Keywords : FDI, Exchange Rates, Fiscal Policy.}

\section{INTRODUCTION}

With the advent of globalization the economies of most of the sovereign countries are connected and hence calling world as a global village is not an exaggeration. The Asian countries, post-colonization opened most of the sectors of their respective economies and hence it is important to know the trends in the international trade scenario which will help the policymakers to align the domestic policies of their respective countries which is beneficial to their own economy. Analyzing the external and internal macroeconomic factors one can strengthen the economic position of the country and make the products of the country more competitive over others and thereby gaining a greater stay in the geopolitics. With boosting the image of a country in the International arena, it will also be able to influence the policies of the multilateral financial institutions and international trade organizations with its bargaining power. To excel in any sector, proper research and study of the same

Revised Manuscript Received on September 25, 2019

A.Paul Williams Ph.D Scholar, Dept of International Business, Alagappa University, Karaikudi. is necessary to gain expertise in that particular sector and hence this study is about the fluctuations in currency because of the FDI inflows. Some of the Asian countries like China, India, Phillipines, Qatar, and Singapore gained a lot with the globalization as they integrated their economies with the global value chains much earlier than the now developing Central Asian nations. So evaluating the Asian countries currencies would be helpful in knowing their competitive position in the global economy.

\section{NEED FOR THE STUDY}

This study helps in identifying the role of FDI inflows as a Macroeconomic Variable responsible for the fluctuations in the currency. With this analysis one will be able to better manage the economy according to the needs of the market. This will help the policy-makers to plan the fiscal policies accordingly and also the central banks will chart down the monetary policy in a way that is in co-ordination with fiscal policy of the government of the respective countries. The government can also take steps in the direction that makes the different sectors of the economy integrate itself with the global value chains. By doing so, the exports and imports of the economy can be regulated that is favoring the balance of trade which in turn will lead to improvement of FOREX reserves. When FOREX reserves are sufficient, they can act as a buffer in case there is a shock in the international arena. Also when the relationship of FDI inflows and Exchange rates are known we can identify the grey areas that needs to be addressed which in turn helps in deciding the diversification of the trading partners and thereby reducing the risks. With a better understanding of the currency fluctuations the government can make its policies in line with that of the global happenings that is favoring their respective national interest. Also one can able to protect the domestic players in case there is volatility in the exchange rates and thereby strengthening the image of the country in terms of robust regulatory mechanisms which inturn will gain the confidence of the investors and hence the market will be attractive for foreign investments both directly (FDI) and indirectly, through financial markets (FII). Considering the fact that major import basket forms the crude oil, any minor tensions in the geopolitics might have a major impact on the current account deficit of the country and hence the study might help the policymakers in this direction.

It will help in identifying the areas where the country has to diversify its trading partners so that it is not affected by a unilateral sanction by a country.

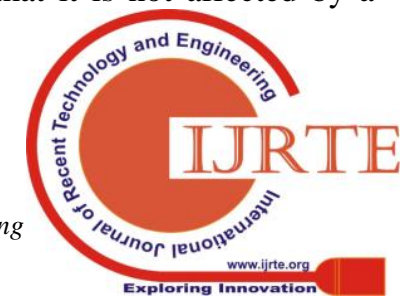




\section{REVIEW OF LITERATURE}

Farhana and Nushrat (2015) explained that the floating exchange positively impacted the economy of Bangladesh and they have considered four macroeconomic fundamentals which are export, import, remittances from the expatriates, forex reserves for studying the exchange rates. They have also concluded by telling that for a developing country like Bangladesh, the government and the central bank should play proactive role in regulating the economy. Fayyaz (2014) tested the empirical relationship between the exchange rates and economic fundamentals for the developing Asian countries using both pool and panel estimations and also found that economic, social and political factors also plays a major role in the stability of the exchange rates. Ravindran and Soroush (2013) emphasizes the significant role played by the exchange rates in the international trade and have taken yearly exchange rates of three countries along with relative interest rates to study the impact. They have used bootstrapping technique to increase the size of the sample and study the regression. They have stressed on psychological factors such as investors confidence plays a major role in determining the exchange rates to an extent. Devereux and Charles Engel (1999) investigated the implications of internationalized production on the exchange rates and also examined the price settings (i.e) whether the prices are set in the currency of producers or consumers to determine the optimality of the exchange rates. They found that when prices are set in producer's currency the flexible exchange rate is preferred when the economy is large enough and less prone to risks. Also the flexible regime is always preferred when the prices are set in consumer's currency because they are kept aloof of the foreign monetary shocks. Chi-wei su (2012) studied the relationship between the Chinese currency renminbi (RMB) exchange and macroeconomic variables and found out that there is a nonlinear relationship between the two. He also shows the evidence that in long run, the results support the hypothesis of an asymmetrical error-correction process in china.

\section{OBJECTIVES OF THE STUDY}

- To study the influence of FDI inflows on currency fluctuations with special reference to selected Asian countries currencies.

- To study the relationship of FDI inflows and currency fluctuations in selected Asian countries.

\section{SCOPE OF THE STUDY}

The study is confined to select Asian countries such as China, India, Singapore, Philippines, and Qatar their currency fluctuations because of the FDI inflows. Also other macroeconomic variables such as the interest rates, inflation, employment rates are not considered in the study. The problematic areas with respect to the FDI inflows can be identified and necessary steps can be taken to gain the trust of the investors. This study will help in determining if FDI inflows are responsible for the fluctuations in the currency which will have adverse factors on the GDP, inflation, employment rate, current account deficits, and growth in the domestic economy of the country. The fiscal and monetary

policies can be planned accordingly. It also helps in framing the policies which favors the domestic players in better cater to the needs of the foreign investor which in turn will help in spurring growth in the domestic economy, thereby raising the income of the household and reducing the inequalities which will lead to better standards of living. It also helps in diversifying the source of investments from short term investments that is the foreign institutional investors (FII now FPI) as they are not stable to the more stable foreign direct investments (FDI) which will help in the development of the economy. With the stable economy it will be easy for the country to focus on its development needs.

\section{RESEARCH METHODOLOGY}

\section{Period of Study}

This study was conducted for a period of twenty years from 1998 to 2018.

\section{Sources of Data}

The study is based on the secondary data which is from the websites of central banks of the respective countries and websites of the multilateral financial institutions such as the World Bank, Asian Development Bank, and IMF.

\section{Analytical tools used in the study}

The necessary statistical tools needed to evaluate the fluctuations of currencies such as Linear regression and correlation is used.

\section{Data Analysis and Interpretation}

The dependent variable here is the Exchange rates of the selected Asian countries and the independent variable is FDI inflows in the respective countries. The researcher has used correlation to determine the relationship between the dependant and the independent variable and linear regression to determine the level of influence the FDI inflows has on the exchange rates of the selected Asian countries' currencies.

\section{Hypothesis:}

$\mathbf{H}_{0}$ : There is no significant relationship between FDI inflows and Exchange rates and no significant influence of FDI inflows on Exchange rates in China.

$\mathbf{H}_{1}$ : There is no significant relationship between FDI inflows and Exchange rates and no significant influence of FDI inflows on Exchange rates in India.

$\mathbf{H}_{2}$ : There is no significant relationship between FDI inflows and Exchange rates and no significant influence of FDI inflows on Exchange rates in Philippines.

$\mathbf{H}_{3}$ : There is no significant relationship between FDI inflows and Exchange rates and no significant influence of FDI inflows on Exchange rates in Qatar.

$\mathbf{H}_{4}$ : There is no significant relationship between FDI inflows and Exchange rates and no significant influence of FDI inflows on Exchange rates in Singapore. 
Table: 1 (Correlation and Regression analysis of FDI inflows and Exchange rates)

Source: Researcher computed using SPSS 21

\begin{tabular}{|c|c|c|c|c|c|c|c|c|c|}
\hline \multirow{2}{*}{$\begin{array}{l}\text { Exchange } \\
\text { Rates/ FDI }\end{array}$} & \multicolumn{2}{|c|}{ Coefficient } & \multicolumn{2}{|c|}{ t-Statistic } & \multicolumn{2}{|c|}{ P-Value } & \multirow[t]{2}{*}{$\mathbf{R}^{2}$} & \multirow[t]{2}{*}{ F-statistic } & \multirow[t]{2}{*}{ Correlation } \\
\hline & $\mathbf{C}$ & & $\mathbf{C}$ & & $\mathbf{C}$ & & & & \\
\hline China & 8.71 & -9.34 & 64.79 & -11.9 & .00 & .0000 & .88 & 143.80 & $\begin{array}{l}-0.939839 \\
(0.0000)\end{array}$ \\
\hline India & 42.8 & 3.29 & 16.72 & 3.45 & .00 & .0028 & .39 & 11.96 & $\begin{array}{l}0.631848 \\
(0.0028)\end{array}$ \\
\hline Philippines & 47.1 & 8.66 & 28.31 & .227 & .00 & .8223 & .002 & .05 & $\begin{array}{l}0.052176 \\
(0.8223)\end{array}$ \\
\hline Qatar & 3.64 & 1.47 & 3.32 & 3.64 & .00 & .0017 & - & - & $\begin{array}{l}\mathrm{NA} \\
\text { (NA) }\end{array}$ \\
\hline Singapore & 1.73 & -5.54 & 35.27 & -5.50 & .00 & .0000 & .614 & 30.26 & $\begin{array}{l}-0.783793 \\
(0.0000)\end{array}$ \\
\hline
\end{tabular}

In the above table, FDI inflows are the independent variables and the Exchange rates of respective countries currencies are the dependent variables. For China the correlation shows that there is a strong negative correlation ( $\mathrm{p}$ value $<0.05$ ) between the FDI inflows and exchange rates of Chinese yuan and this is complemented by the results of the regression model created which shows that there is a significant influence of FDI inflows on the exchange rates(p value $<0.05)$. Hence the null hypothesis has been rejected for China. The $\mathrm{R}^{2}$ value shows that 88 percent variation in exchange rates is caused by the FDI inflows.

For India the correlation shows that there is a moderate positive correlation ( $p$ value $<0.05$ ) between the FDI inflows and exchange rates of Indian rupee and this is complemented by the results of the regression model created which shows that there is a significant influence of FDI inflows on the exchange rates( $\mathrm{p}$ value $<0.05$ ). Hence the null hypothesis has been rejected for India. The $\mathrm{R}^{2}$ value shows that 39 percent variation in exchange rates is caused by the FDI inflows.

For Philippines the correlation shows that there is no correlation ( $p$ value $>0.05$ ) between the FDI inflows and exchange rates of Phillipine peso and this is complemented by the results of the regression model created which shows that there is no significant influence of FDI inflows on the exchange rates $(p$ value $>0.05$ ). Hence the null hypothesis has been accepted for Philippines.

The results of Qatar are quite amazing since they follow fixed exchange rate regime and hence the correlation between the dependant and the independent variable cannot be found and but the regression model shows that there is a significant influence of FDI inflows on the exchange rates of Qatar.

For Singapore, the correlation shows that there is a strong negative correlation ( $\mathrm{p}$ value $<0.05$ ) between the FDI inflows and exchange rates of Indian rupee and this is complemented by the results of the regression model created which shows that there is a significant influence of FDI inflows on the exchange rates( $\mathrm{p}$ value $<0.05$ ). Hence the null hypothesis has been rejected for Singapore. The $\mathrm{R}^{2}$ value shows that 61 percent variation in exchange rates is caused by the FDI inflows.

\section{CONCLUSION}

With the integration of Asian economies with the world, the challenges faced now is entirely different from what the Asian countries faced earlier in the pre-globalization era. The predictability of the economy is important to attract the investments. Hence, the understanding of the currency volatility is an even more important determinant in the policy making. By better knowing the factors that cause volatility in the currency rates the government of the day can preplan its fiscal policy and regulate its expenditure and borrowings. By doing so, it can balance between economic growth and inflation and at the same time it can keep the unemployment levels under control. The central bank will also be able to make the policy rates (repo rates, bank rates, reverse repo rates) that matches with the needs of the economy and also the government can alter its policies so that the expenditures and the debt are in control. For this regulation of economy there should be co-ordination between the authorities responsible for the fiscal and monetary policies. Except Philippines other countries have a correlation and there is a significant influence of FDI inflows on the exchange rates. This shows that the countries should recognize the importance of FDI inflows which brings in the capital, technology and also the managerial expertise. Given the trade tensions that is prevailing in the world and the conservative attitude of the western countries, the Asian countries could come together and prosper together by integrating themselves.

\section{ACKNOWLEDGMENT}

The research paper is funded by RUSA (Rashtriya Uchchatar Shiksha Abhiyan) Phase 2.0 Scheme by Ministry of Human Resource Development (MHRD), India. The author filled with gratitude to the anonymous referees of journal for their useful suggestions to refine the paper quality.

\section{REFERENCES}

1. Farhana and Nushrat (2015),"Effects of macroeconomic variables on the exchange rates of Bangladesh", International journal of scientific and engineering research, pp 1028-1034

2. Fayyaz (2014), 'Impact of macroeconomic variables on exchange rates: Empirical evidence 
from developing asian countries", SSRN, pp 1-28

3. Ravindran and Soroush (2013)," Influence of macroeconomic variables on exchange rates", Journal of economics, business and management, pp 276-281

4. Devereux and Charles engel (1999),"'The optimal choice of exchange rate regime: price-setting rules and internationalized production", national bureau of economic research, pp 1-31

5. Chi-wei su(2012),'The relationship between exchange rate and macroeconomic variables in china", research gate, pp 33-56 